\title{
Nutrient Content and Uptake by Soybean (Glycine max L. Merril) as Influenced by use of Enriched Compost and Biofertilizers
}

\author{
Kamlesh Yadav, S.C. Meena*, Gajanand Jat, R.H. Meena and Atul Dhansil \\ Department of Soil Science and Agricultural Chemistry \\ Rajasthan College of Agriculture, MPUAT, Udaipur, Rajasthan, India \\ *Corresponding author
}

\begin{abstract}
A B S T R A C T
\section{Keywords}

Nutrient Content

Uptake

Glycine max

Enriched Compost

and Biofertilizers

Article Info

Accepted:

25 June 2019

Available Online:

10 July 2019

The field investigation was carried out at Agronomy Instructional farm, Rajasthan College of Agriculture, MPUAT, Udaipur, to the evaluate influence of combined use of enriched compost and biofertilizers soybean nutrition grown under typic haplustepts clay loam soil. The results obtained from field investigation indicated a significant improvement in content and uptake of micro and macro nutrient. The data indicates that application of enriched compost $(5 \mathrm{t})$ ha $^{-1}$ along with Rhizobium + PSB recorded significant improvement in $\mathrm{N}, \mathrm{P}_{2} \mathrm{O}_{5}, \mathrm{~K}_{2} \mathrm{O}, \mathrm{Zn}, \mathrm{Cu}, \mathrm{Fe}$ and $\mathrm{Mn}$ content and uptake over control after harvest of soybean crop. The treatment enriched compost $(4 \mathrm{t}) \mathrm{ha}^{-1}$ along with Rhizobium + PSB, enriched compost $(5 \mathrm{t}) \mathrm{ha}^{-1}+$ Rhizobium $\left(\mathrm{T}_{8}\right)$ and enriched compost $(5 \mathrm{t}) \mathrm{ha}^{-1}+\mathrm{PSB}\left(\mathrm{T}_{9}\right)$ were found statistically at par with enriched compost $(5 \mathrm{t}) \mathrm{ha}^{-1}$ along with Rhizobium + PSB $\left(\mathrm{T}_{10}\right)$ in respect to $\mathrm{N}, \mathrm{P}_{2} \mathrm{O}_{5}, \mathrm{~K}_{2} \mathrm{O}, \mathrm{Zn}, \mathrm{Cu}, \mathrm{Fe}$ and $\mathrm{Mn}$ content.

\section{Introduction}

India has a prominent position on oilseed map of the world, both in respect to area and production. In terms of acreage, production and economic value, oilseeds are second only to food grains. India is the $4^{\text {th }}$ largest edible oil economy in the world after USA, China \& Brazil and contributes about 10 per cent of the world oilseeds production, 6-7\% of the global production of vegetable oil, and nearly 7 percent of protein meal. Soybean [Glycine $\max$ (L.) Wilczek] is a globally important oilseed crop and source of high-quality protein for human consumption, used as

fodder for animal and is also important in improved crop rotation systems (Manyong et al., 1996; Carsky et al., 1997).Soils having low concentrations of plant available nutrients and $\mathrm{AOC}$, alkaline $\mathrm{pH}$, low EC values, and low soil enzyme activity generally gives low yields of crops (Li et al., 2017).The element phosphorus plays a crucial role in plant development and yield of crops. The region of experimentation had medium phosphorus availability which may be due to the fixation of phosphorus under alkaline condition and this leads to the reduction in decrease in crop yields as reported by Ghosal et al., 2012. The organic manure is considered as balanced
\end{abstract}


nutrient source because it has both macro and micro nutrients (Rekha et al., 2018). Rock phosphate (RP) is a natural $\mathrm{P}$ source and could be used as an alternative to chemical phosphatic fertilizers, but it is only soluble under acidic conditions and is not applicable to alkaline soils (Caravaca et al., 2004). Recently, RP solubilization with the use of microbes having phosphate solubilizing ability is gaining more attention (Gyaneshwar et al., 2002; Vassilev et al., 2006). In this regard, phosphate-solubilizing bacteria could be utilized for the solubilization of RP as bacterial solubilization is more efficient than fungi and could easily be utilized for industrial application (Yadav et al., 2017). RP along with phosphate-solubilizing bacteria utilized as $\mathrm{P}$ source in alkaline soils. However, the efficiency of bacteria to solubilize RP providing an easily available nutrient source for microbes such as organic fertilizer produced through composting. It has been well known that combined application of RP, phosphate solubilizing bacteria, and organic fertilizer resulted in better agronomic efficiency than chemical lphosphatic fertilizers when applied in equal amounts of total $\mathrm{P}_{2} \mathrm{O}_{5}$ basis (Yadav et al., 2017). Recently, interest has been developed in compound fertilizers composed of suitable phosphate solubilizing bacteria, organic matter, and RP. Additionally, the organic matter in the form of organic fertilizers improves soil physicochemical properties and increases the amount of active organic carbon, thereby improving soil quality and soil vitality (Biau et al., 2012). However, sole application of organic fertilizers cannot support food production from poor/less fertile soils for the world population which is increasing at an alarming rate.

\section{Materials and Methods}

The experiment was conducted at Agronomy, Instructional Farm, Rajasthan College of Agriculture, Udaipur (Rajasthan) in kharif
2018 on sandy clay loam soil which is slightlyalkaline in nature comprised of 10 treatments, only RDF, Enriched compost (3 t) $\mathrm{ha}^{-1}+$ Rhizobium, Enriched compost $(3 \mathrm{t}) \mathrm{ha}^{-1}$ + PSB, Enriched compost $(3 \mathrm{t}) \mathrm{ha}^{-1}+$ Rhizobium + PSB, Enriched compost (4 t) ha ${ }^{-1}$ + Rhizobium, Enriched compost $(4 \mathrm{t}) \mathrm{ha}^{-1}+$ PSB, Enriched compost (4t) ha ${ }^{-1}+$ Rhizobium + PSB, Enriched compost (5 t) $\mathrm{ha}^{-1}+$ Rhizobium, Enriched compost (5 t) ha ${ }^{-1}+$ PSB and Enriched compost (t) ha $^{-1}+$ Rhizobium + PSB. These treatments were evaluated under randomized block design (RBD) with three replications. Soybean cultivar (JS -9560) was taken as test crop. The enriched compost was prepared as method followed by Biswas and Narayanasamy. The enriched compost contains $\mathrm{N}(0.75 \%), \mathrm{P}_{2} \mathrm{O}_{5}(2.03 \%)$ and $\mathrm{K}_{2} \mathrm{O}$ $(0.67 \%)$.

\section{Results and Discussion}

Results of indicated that combined use of enriched compost along with biofertilizers improved the nutrient content and uptake by the soybean crop. Data presented in Table 1 showed that integrated use of enriched compost $(5 \mathrm{t}) \mathrm{ha}^{-1}$ along with Rhizobium + PSB brought about significant improvement in $\mathrm{N}, \mathrm{P}, \mathrm{K}, \mathrm{Zn}, \mathrm{Cu}, \mathrm{Mn}$, and Fe content and uptake over unfertilized control. This indicated a favorable soil micro climate régime induced by the incorporation of enriched compost and biofertilizer.

RP-enriched organic fertilizer, showed an improvement in the availability of $\mathrm{N}$ and $\mathrm{P}$ (Ditta et al., 2018). Inoculation of black gram seeds with Rhizobium and PSB enhance the N and $\mathrm{P}$ mineralization (Jangir et al., 2017). The organic acids produced during composting by the soil microbes (PSMs) might be a reason to decrease the $\mathrm{pH}$ of the material being composted, i.e., RP and compost, and resulted in an increased release of $\mathrm{P}$ from $\mathrm{RP}$-enriched organic fertilizer (Rashid et al., 2004). 
Table.1 Effect of enriched compost and bio-fertilizers on N, P, K (\%) content in seed and straw of soybean

\begin{tabular}{|c|c|c|c|c|c|c|}
\hline \multirow[t]{2}{*}{ Treatments } & \multicolumn{2}{|c|}{ Nitrogen } & \multicolumn{2}{|c|}{ Phosphorus } & \multicolumn{2}{|c|}{ Potassium } \\
\hline & Seed & Straw & Seed & Straw & Seed & Straw \\
\hline Control & 5.677 & 1.030 & 0.241 & 0.198 & 1.001 & 0.918 \\
\hline Enriched compost $(3$ t) + Rhizobium & 6.130 & 1.153 & 0.258 & 0.223 & 1.056 & 1.036 \\
\hline Enriched compost $(3 \mathrm{t})+$ PSB & 5.947 & 1.122 & 0.266 & 0.227 & 1.054 & 1.034 \\
\hline Enriched compost $(3 \mathrm{t})+$ Rhizobium $+\mathrm{PSB}$ & 6.366 & 1.213 & 0.282 & 0.251 & 1.094 & 1.080 \\
\hline Enriched compost $(4$ t) + Rhizobium & 6.687 & 1.340 & 0.314 & 0.258 & 1.130 & 1.228 \\
\hline Enriched compost (4 t) + PSB & 6.607 & 1.311 & 0.322 & 0.275 & 1.128 & 1.225 \\
\hline Enriched compost (4 t) + Rhizobium +PSB & 6.930 & 1.420 & 0.341 & 0.304 & 1.166 & 1.285 \\
\hline Enriched compost $(5$ t) + Rhizobium & 7.094 & 1.451 & 0.369 & 0.328 & 1.170 & 1.291 \\
\hline Enriched compost $(5 \mathrm{t})+$ PSB & 6.964 & 1.440 & 0.376 & 0.335 & 1.167 & 1.288 \\
\hline $\begin{array}{l}\text { Enriched compost }(5 \text { t) + Rhizobium + } \\
\text { PSB }\end{array}$ & 7.001 & 1.459 & 0.388 & 0.359 & 1.172 & 1.304 \\
\hline SEm \pm & 0.072 & 0.017 & 0.003 & 0.003 & 0.011 & 0.011 \\
\hline $\mathrm{CD}(\mathrm{P}=\mathbf{0 . 0 5})$ & 0.214 & 0.050 & 0.010 & 0.009 & 0.032 & 0.032 \\
\hline
\end{tabular}


Table.2 Effect of enriched compost and bio-fertilizers on $\mathrm{Zn}, \mathrm{Cu}, \mathrm{Fe}, \mathrm{Mn}$ content (ppm) in seed and straw of soybean

\begin{tabular}{|c|c|c|c|c|c|c|c|c|}
\hline Treatments & & n & & & & & & \\
\hline & Seed & Straw & Seed & Straw & Seed & Straw & Seed & Straw \\
\hline Control & 34.220 & 17.841 & 13.143 & 4.683 & 29.563 & 46.160 & 38.727 & 45.617 \\
\hline Enriched compost $(3 \mathrm{t})+$ Rhizobium & 35.249 & 19.257 & 13.560 & 5.053 & 30.580 & 47.928 & 39.973 & 47.173 \\
\hline Enriched compost $(3 \mathrm{t})+$ PSB & 35.232 & 19.250 & 13.527 & 5.040 & 30.557 & 47.856 & 39.927 & 47.125 \\
\hline Enriched compost $(3 \mathrm{t})+$ Rhizobium + PSB & 35.947 & 19.513 & 13.962 & 5.334 & 31.480 & 49.201 & 41.126 & 48.271 \\
\hline Enriched compost $(4 \mathrm{t})+$ Rhizobium & 36.555 & 20.256 & 14.384 & 5.537 & 32.587 & 50.569 & 42.816 & 50.013 \\
\hline Enriched compost $(4 \mathrm{t})+$ PSB & 36.542 & 20.241 & 14.333 & 5.529 & 33.417 & 50.498 & 42.778 & 49.974 \\
\hline Enriched compost (4 t) + Rhizobium +PSB & 37.147 & 20.671 & 14.804 & 5.798 & 33.520 & 51.924 & 44.001 & 51.226 \\
\hline Enriched compost $(5 \mathrm{t})+$ Rhizobium & 37.374 & 20.917 & 14.048 & 5.819 & 33.814 & 52.021 & 44.562 & 51.964 \\
\hline Enriched compost $(5 \mathrm{t})+$ PSB & 37.363 & 20.901 & 13.998 & 5.816 & 33.771 & 52.007 & 44.548 & 51.941 \\
\hline Enriched compost $(5$ t) + Rhizobium + PSB & 37.559 & 20.948 & 14.131 & 5.851 & 34.018 & 52.074 & 44.816 & 52.004 \\
\hline SEm \pm & 0.196 & 0.126 & 0.113 & 0.056 & 0.281 & 0.424 & 0.385 & 0.370 \\
\hline $\mathrm{CD}(\mathrm{P}=\mathbf{0 . 0 5})$ & 0.581 & 0.373 & 0.337 & 0.165 & 0.834 & 1.260 & 1.143 & 1.098 \\
\hline
\end{tabular}


Table.3 Effect of enriched compost and bio-fertilizers on N, P, K uptake $\left(\mathrm{kg} \mathrm{ha}^{-1}\right)$ by seed and straw of soybean

\begin{tabular}{|c|c|c|c|c|c|c|}
\hline \multirow[t]{2}{*}{ Treatments } & \multicolumn{2}{|c|}{ Nitrogen uptake by } & \multicolumn{2}{|c|}{ Phosphorus uptake by } & \multicolumn{2}{|c|}{ Potassium uptake by } \\
\hline & Seed & Straw & Seed & Straw & Seed & Straw \\
\hline Control & 50.18 & 15.03 & 2.12 & 2.89 & 8.94 & 13.381 \\
\hline Enriched compost $(3$ t) + Rhizobium & 62.36 & 19.61 & 2.63 & 3.80 & 10.77 & 17.584 \\
\hline Enriched compost $(3 \mathrm{t})+$ PSB & 61.32 & 18.99 & 2.74 & 3.85 & 10.86 & 17.594 \\
\hline $\begin{array}{l}\text { Enriched compost }(3 \mathrm{t})+\text { Rhizobium }+ \\
\text { PSB }\end{array}$ & 78.84 & 23.05 & 3.46 & 4.78 & 13.44 & 20.501 \\
\hline Enriched compost $(4$ t) + Rhizobium & 90.97 & 28.24 & 4.27 & 5.40 & 15.37 & 25.836 \\
\hline Enriched compost $(4 t)+$ PSB & 90.85 & 27.42 & 4.43 & 5.75 & 15.48 & 25.550 \\
\hline Enriched compost $(4$ t) + Rhizobium +PSB & 108.83 & 32.72 & 5.35 & 6.98 & 18.29 & 29.526 \\
\hline Enriched compost (5 t) + Rhizobium & 114.13 & 34.06 & 5.92 & 7.68 & 18.76 & 30.160 \\
\hline Enriched compost $(5$ t) + PSB & 112.95 & 33.51 & 6.09 & 7.79 & 18.90 & 29.876 \\
\hline $\begin{array}{l}\text { Enriched compost }(5 \mathrm{t})+\text { Rhizobium }+ \\
\text { PSB }\end{array}$ & 116.05 & 34.33 & 6.41 & 8.42 & 19.35 & 30.545 \\
\hline SEm \pm & 3.31 & 0.98 & 0.14 & 0.20 & 0.48 & 0.806 \\
\hline $\mathrm{CD}(\mathrm{P}=0.05)$ & 9.83 & 2.91 & 0.42 & 0.60 & 1.42 & 2.40 \\
\hline
\end{tabular}


Table.4 Effect of enriched compost and bio-fertilizers on $\mathrm{Zn}, \mathrm{Cu}, \mathrm{Fe}, \mathrm{Mn}$ uptake (ppm) by seed and straw of soybean

\begin{tabular}{|c|c|c|c|c|c|c|c|c|}
\hline \multirow[t]{2}{*}{ Treatments } & \multicolumn{2}{|c|}{ Zn uptake by } & \multicolumn{2}{|c|}{ Cu uptake by } & \multicolumn{2}{|c|}{ Fe uptake by } & \multicolumn{2}{|c|}{ Mn uptake by } \\
\hline & Seed & Straw & Seed & Straw & Seed & Straw & Seed & Straw \\
\hline Control & 301.00 & 259.72 & 117.03 & 14.57 & 260.64 & 672.83 & 341.90 & 1124.02 \\
\hline Enriched compost (3 t) + Rhizobium & 358.44 & 328.56 & 138.21 & 17.07 & 312.55 & 818.47 & 408.42 & 1360.26 \\
\hline Enriched compost $(3 \mathrm{t})+$ PSB & 363.37 & 325.82 & 139.36 & 16.92 & 315.14 & 809.44 & 412.35 & 1342.64 \\
\hline Enriched compost (3 t) + Rhizobium +PSB & 440.42 & 370.28 & 171.94 & 18.98 & 387.14 & 933.93 & 503.47 & 1551.86 \\
\hline Enriched compost (4 t) + Rhizobium & 497.38 & 425.90 & 195.61 & 21.03 & 443.57 & 1063.53 & 582.57 & 1773.01 \\
\hline Enriched compost $(4 \mathrm{t})+$ PSB & 501.85 & 422.73 & 196.90 & 20.87 & 459.26 & 1053.80 & 587.35 & 1783.40 \\
\hline Enriched compost $(4 \mathrm{t})+$ Rhizobium $+\mathrm{PSB}$ & 582.84 & 474.49 & 232.28 & 22.97 & 525.83 & 1191.98 & 689.87 & 1952.19 \\
\hline Enriched compost (5 t) + Rhizobium & 599.99 & 488.43 & 225.32 & 23.37 & 542.40 & 1217.09 & 714.57 & 2055.74 \\
\hline Enriched compost $(5$ t) + PSB & 605.67 & 486.26 & 226.72 & 23.26 & 546.73 & 1207.67 & 720.39 & 2067.85 \\
\hline Enriched compost $(5$ t) + Rhizobium + PSB & 620.23 & 490.92 & 233.25 & 23.44 & 562.74 & 1230.12 & 737.01 & 2088.81 \\
\hline SEm \pm & 15.41 & 11.88 & 5.97 & 0.61 & 12.79 & 36.46 & 15.86 & 76.22 \\
\hline $\mathrm{CD}(\mathbf{P}=\mathbf{0 . 0 5})$ & 45.79 & 35.31 & 17.73 & 1.80 & 37.99 & 108.34 & 47.13 & 226.46 \\
\hline
\end{tabular}


The application of vermicompost along with phosphorus solubilizing bio-inoculants reduce $\mathrm{P}$ fixation by releasing considerable $\mathrm{P}$ and variety of organic acids during decomposition and as well as inducing chelating effects on micronutrients which probably enhanced the availability of phosphorus. According to Jansson et al.,1988; Shekhawat et al., 2017, it may also be due to the production of enzymes and chelating agents (organic acids) by the microbes which play a critical role in the mineralization of organic $\mathrm{P}$ present in the compost. Similarly, reduction in $\mathrm{pH}$ of materials being composted might also be due to the production of a large amount of carbon dioxide during composting, which forms carbonic acids after combining with water. Applications of enriched compost not only solubilize the availability of nutrients but also contains significant amount of $\mathrm{N}, \mathrm{P}$ and K.The production of organic acids such as acetate, lactate, oxalate, tartrate, succinate, citrate, gluconate, ketogluconate, glycolate, etc., during the composting process by the microbes might have resulted in increasing the availability of nutrients especially $\mathrm{P}$ as observed the chemical analysis after composted material (Ditta et al., 2017). Due to mineralization of micronutrients present in compost by microorganisms, availability of carbon and other nutrients is increased during composting, which increases the microbial population and ultimately the production of organic acids (Biswas and Narayanasamy, 2006; Chakraborty et al., 2011). Significant improvement in uptake of both macro and micro nutrient were seen which might be better root development and translocation of assimilated nutrients as observed by Rekha $e t$ al., 2018; Shankar et al., 2014. This could be also due to increased root nodulation through better root development and more nutrient availability, resulting in better absorption and utilization of all the plant nutrients (Singh and Pareek, 2003) The greater uptake of nutrient might also be due to the low loss of solubilized nutrient due to chelate formation. The uptake of micronutrient may be enhanced due to synergetic effect between macro and micronutrient.

In conclusion, excessive use of chemical fertilizers leads to the deterioration of soil quality and health. Use of organic manure or nutrient enriched organic manure could be best alternative to these high cost inputs to maintain soil health.

\section{References}

Biau, A., F. Santiveri, I. Mijangos, and J. Lloveras. 2012. Impact of organic and mineral fertilizers on soil quality parameters and the productivity of irrigated maize crops in semiarid regions. European Journal of Soil Biology,53 (6):56-61.

Caravaca, F., M. M. Alguacil, R. Azcón, G. Diaz, and A. Roldán. 2004. Comparing the effectiveness of mycorrhizal inoculation and amendment with sugar beet, rock phosphate and Aspergillus niger to enhance field performance of the leguminous shrub Dorycnium pentaphyllum L. Applied Soil Ecology, 25 (2):169-80.

Carsky, R.J., R. Abiadoo, K.E. Dashiell and N. Sanginga. 1997. Effect of soybean on subsequent maize grain yield in Guinea savannah of West Africa. African Crop Science Journal, 5: 31-39.

Ghosal, P. K. And Chakraborty, T. 2012. Comparative solubility study of four phosphatic fertilizers in different solvents and the effect of soil. Resources and Environment, 2(4):175-179.

Gyaneshwar, P., N. Kumar, L. J. Parekh, and P. S. Poole. 2002. Role of soil microorganisms in improving P nutrition of plants. Plant and Soil, 245:83-93.

Jangir, C.K., Singh, D.P., Meena, R.H. and Yadav, M. 2017. Effect of fertility levels and biofertilizers on physical and chemical properties of soil under Blackgram (Vigna mungo L.). International Journal of Current Microbiology and Applied Sciences, 6(3): 223228.

Li, M., Li,Q., Yun,J., Yang, X., Wang, X., Lian,B. and Lu, C. 2017. Bio-organic-mineral fertilizer can improve soil quality and promote the growth and quality of water spinach.Canadian Journal 
of Soil Science, 97(4):552-60.

Manyong, V.M., K.E. Dashiell, B. Oyewole and G. Blahut, 1996. Spread of new Soybean varieties in a traditional soybean growing area of Nigeria. A Seminar Paper in the Second Symposium of the African Association of Farming Systems Research Extension and Training (AAFSRET), 151-162.

Nagar, R.K., Goud, V.V., Kumar, Rajesh and Kumar, Ravindra. 2016. Effect of organic manures and crop residue management on physical, chemical and biological properties of soil under pigeon pea based intercropping system. International Journal of Farm Sciences, 6(1): 101-113.

Rekha, K., Pavaya, R.P., Malav, J.K., Chaudhary, N., Patel, I. M. and Patel, J.K. 2018. Effect of FYM, phosphorus and PSB on yield, nutrient content and uptake by green gram (Vigna radiata (L.) Wilckzek) on loamy sand. International Journal of Chemical Studies, 6(2): 1026-1029.

Vassilev, N., M. Vassileya, and I. Nikolaeva. 2006. Simultaneous $\mathrm{P}$ solubilizing and biocontrol activity of microorganisms: Potentials and future trends. Applied Microbiology and Biotechnology, 71:137-44.

Yadav, H., R. Fatima, A. Sharma, and S. Mathur. 2017. Enhancement of applicability of rockphosphate in alkaline soilsby organic compost. Applied Soil Ecology, 113:80-85.

Rashid, M., Khalil, S., Ayub, N., Alam, S. and Latif, F. 2004. Organic acids production and phosphate solubilization by phosphate solubilising microorganisms (PSM) under in vitro conditions. Pakistan Journal Biological Science, 7:187-196.

Jansson, M., Olsson, H. andPettersson, K.1988. Phosphatases; origin, characteristics and function in lakes. Hydrobiology, 170:157-175.

Shekhawat, A.S., Purohit, H.S., Jat, G., Meena, R. and Regar, M.K., 2018. Efficacy of phosphorus, vermicompost and biofertilizers on soil health and nutrient content \& uptake of black gram (Vigna mungo L.). International Journal of Current Microbiology and Applied Science, 6(2), pp.3518-3521.

Ditta, A., Muhammad, J., Imtiaz, M., Mehmood, S., Qian, Z. and Tu, S. 2017. Application of rock phosphate enriched composts increases nodulation, growth and yield of chickpea. International Journal of Recycling of Organic Waste in Agriculture, 7:33-40.

Biswas, D. and Narayanasamy, G. 2006. Rock phosphate enriched compost: an approach to improve low-grade Indian rock phosphate. Bioresource Technology, 97:2243-2251

Chakraborty, A., Chakrabarti, K., Chakraborty, A. and Ghosh, S. 2011. Effect of long-term fertilizers and manure application on microbial biomass and microbial activity of a tropical agricultural soil. Biology and Fertility of Soils, 47:227-233.

Rekha, K., Pavaya, R.P., Malav, J.K., Chaudhary, N., Patel, I. M. and Patel, J.K. 2018. Effect of FYM, phosphorus and PSB on yield, nutrient content and uptake by green gram (Vigna radiata (L.) Wilckzek) on loamy sand. International Journal of Chemical Studies, 6(2): 1026-1029.

Shankar, M.A., Maruthi, S.G.R., Nagamani, M.K. 2014. Micronutrient management for soil fertility, nutrient uptake and productivity of greengram (Vigna radiata) and finger millet (Eleusine coracana) under semiarid Alfisols. Indian Journal of Agronomy, 59(2):306-316.

Singh, B. and Pareek, R.G. 2003. Effect of phosphorus and biofertilizers on growth and yield of mung bean. Indian Journal of Pulses Research, 16: 31-33.

\section{How to cite this article:}

Kamlesh Yadav, S.C. Meena, Gajanand Jat, R.H. Meena and Atul Dhansil. 2019. Nutrient Content and Uptake by Soybean (Glycine max L. Merril) as Influenced by use of Enriched Compost and Biofertilizers. Int.J.Curr.Microbiol.App.Sci. 8(07): 2959-2966.

doi: https://doi.org/10.20546/ijcmas.2019.807.367 